\title{
PREPOSITIONS LEFT AND RIGHT IN AFRIKAANS*
}

\author{
Johan Oosthuizen \\ University of Stellenbosch
}

\section{Introduction}

Afrikaans has various types of adpositional constructions, that is, constructions containing one or more prepositions and/or postpositions. These types include the following, Type A being by far the most common:

Type A: Preposition + DP, as in (1).

(1) op die tafel ('on the table')

onder die klip ('under the rock')

voor Vrydag ('before Friday')

met 'n mes ('with a knife')

per motor ('by car')

vir haar ('for/to her')

tussen ons ('among/between us')

Type B: DP + Postposition, as in (2).

(2) die hele nag deur ('the whole night through')

die wêreld oor ('the world over')

daarvan (there-of, 'of/about it')

hiermee (here-with, 'with this')

kantoor toe $\quad$ (office to, 'to the office') 
Type C: $\quad$ Preposition + DP + Postposition, as in (3).

(3) by die huis verby (by the house past, 'past the house')

in die rivier $\underline{\text { ff }} \quad$ (in the river down, 'down the river')

agter die diewe aan (after the thieves on, 'following/pursuing the thieves')

tussen hulle deur (among/between them through, 'through them')

This paper focuses on what appears to be a subtype of the circumpositional construction illustrated in (3), viz. those cases where the co-occurring preposition and postposition(-like element) are semantically the same in the sense that they express the same information about, for example, location, direction, participant, instrument, goal, etc. Some examples of this subtype, which will be referred to as "(construction-)type D", are given in (4).

Type D: Preposition $_{\mathbf{i}}+\mathbf{D P}+$ Postposition $_{\mathbf{i}}$ (where 'i' shows a relation of 'semantic sameness')

(4) (a) Hy het my $\underline{\text { met }}$ ' $n$ mes $\underline{\text { mee }}$ gesteek he has me with a knife with PART-stab (PART = the past participle prefix ge-) 'He stabbed me with a knife'

(b) Ek het gister met haar saam gepraat I have yesterday with her together PART-talk 'I talked to her yesterday'

(c) Sy braai die vleis $\underline{i n}$ die pan $\underline{i n}$ she fries the meat in the pan in 'She fries the meat in the pan'

(d) Hy wil dit vir iemand anders voor wys he wants-to it for someone else for show 'He wants to show it to someone else'

(e) Die saak is uit my hande uit the matter is out my hands out 'The matter is out of my hands' 
Type D constructions are generally labelled as non-standard, but they are frequently used in the colloquial speech of first language Afrikaans speakers and are also part of, among others, the Western Cape variety of Afrikaans known as "Kaapse Afrikaans". 1

This paper addresses two general questions in connection with Type D circumpositional phrases, neither of which has been dealt with in the literature on Afrikaans generative syntax. The first concerns the categorial status of the postposition-like elements; specifically, whether they belong to the class of "regular" lexical prepositions/postpositions, or whether they should be analysed as some sort of functional category. The second question concerns the underlying structure of Type D phrases; in the course of the discussion attention will also be given to Type B phrases containing the same postposition-like elements as those found with Type D, and to Type A phrases containing prepositions that express the same semantic information as such elements. Section 2 deals with the first question and section 3 with the second. In section 3 we also briefly examine the merit of an analysis of postpositional and circumpositional phrases in German and Dutch that is proposed in (Van Riemsdijk 1990). ${ }^{2}$

\section{Categorial status of postposition-like elements}

Type D phrases, and the postposition-like element occurring in this type, have a number of properties that distinguish them from regular PPs and lexical prepositions. Let us consider four of these properties. Firstly, as is well-known, regular prepositions can be modified by degree adverbs like reg ('right'), reguit ('straight'), direk ('directly'), net ('only'), etc., as in reg in die middel ('right in the middle'), reguit na haar ('straight at her'), direk voor jou ('directly in front of you'), net in Kaapstad ('only in Cape Town'), and so on. ${ }^{3}$ The prepositions met ('with') and vir ('for'), for example, can be modified by net ('only') as in (5), but their postposition-like counterparts mee and voor cannot, as illustrated in (6). (The examples are restricted here to met/mee and vir/voor because their different phonetic forms make them easier to distinguish.) 
(5) (a) Hy het net met haar (mee) gepraat

he has only with her (with) PART-talk

'He talked only to her'

(b) Hoekom moet ek dit net vir daardie meisie (voor) wys?

why must I it only for that girl (for) show

'Why must I show it only to that girl?'

(6) (a) *Hy het (met) haar net mee gepraat $^{4}$

(b) *Hoekom moet ek dit (vir) daardie meisie net voor wys?

Secondly, the postposition-like element in Type D phrases can be omitted without causing any apparent change in meaning. For example, the omission of mee and voor does not take away any semantic information expressed by the sentences in (7). By contrast, the omission of the preposition in Type A phrases, and of the preposition or the postposition in Types B and C, results in ungrammaticality (as illustrated by the (a) sentences in (8)-(10)) or in a change in meaning (as illustrated by the (b) sentences in (8)-(10)).

(7) Type D: (a) Hy het my $\underline{\text { met }}$ 'n mes ( $\underline{\text { mee }})$ gesteek he has me with a knife (with) PART-stab

'He stabbed me with a knife'

(b) Hy wil dit vir iemand anders ( $\underline{\text { voor }}$ ) wys he wants-to it for someone else (for) show

'He wants to show it to someone else'

(8) Type A: (a) Sy sit die boek*(op $)$ die tafel she puts the book *(on) the table 'She puts the book on the table'

(b) Ek sal voor Vrydag kom / Vrydag kom I will before Friday come / Friday come 'I'll come before Friday / (on) Friday' 
(9) Type B: (a) Hulle reis die wêreld $*(\underline{\text { oor }})$

they travel the world *(over)

'They travel all over the world'

(b) Hy het die nag deur gewerk / die nag gewerk

he has the night through PART-work / the night PART-work

'He kept on working throughout the night / worked during the night'

(10) Type C: (a) Hulle hardloop * (agter $)$ die diewe aan

they run $*$ (after) the thieves on

'They're following/pursuing the thieves'

(b) Sy kyk tussen die blare deur / tussen die blare

she looks among the leaves through / among the leaves

'She's looking through the leaves / among the leaves'

The third property concerns the separability of an adposition and the DP that is associated with it. On the one hand, the preposition in Type D phrases may not be stranded when the DP is moved, that is, the preposition must be pied-piped along with the DP. This can be illustrated with the examples in (11) and (12). The preposition was wh-moved in (11)(a) and topicalised in (12)(a) along with the DP; both sentences are grammatical. The (b) sentences, in which the preposition was stranded, are ungrammatical. On the other hand, the postposition-like element in Type D phrases may not be pied-piped along with the DP, that is, it must be stranded when the DP is moved. This is illustrated by the examples in (13) and (14). ${ }^{5}$

(11) (a) Met daardie mes kan jy die vleis sny with that knife can you the meat cut 'With that knife, you can cut the meat'

(b) *Daardie mes kan jy die vleis $\underline{\text { met }}$ sny

(12) (a) Vir watter kandidaat moet ek stem?

For which candidate must I vote

'For which candidate should I vote?'

(b) *Watter kandidaat moet ek vir stem? 
(13) (a) ?*Daardie mes $\underline{\text { mee }}$ kan jy die vleis sny

(b) Daardie mes kan jy die vleis mee sny that knife can you the meat with cut 'That knife, you can cut the meat with'

(14) (a) ${ }^{*} *$ Watter kandidaat voor moet ek stem?

(b) Watter kandidaat moet ek voor stem?

Which cadidate must I for vote

'Which candidate should I vote for?'

The fourth property concerns the abstract Case of the DP argument in adpositional constructions. It is generally assumed in the Minimalist Program (MP) that a lexical preposition is involved in checking the DP's Case in some or other way (or, in Government and Binding (GB) theory, that the preposition assigns structural Case to the DP under government). ${ }^{6}$ However, it could be argued that the postposition-like elements in Type D phrases --- and apparently the postpositions in Types B and C as well --- are not involved in Case-checking/assignment. There are at least two considerations that appear to support this claim.

First, if the postposition-like element in Type D phrases and the postposition in Type C could check/assign Case, a DP in these constructions would be Case-checked twice (or in GB terms, would be assigned double Case): once by the postposition(-like element) and once by the cooccurring preposition. However, multiple Case-checking/assignment does not occur in the Principles and Parameters framework. Given that lexical prepositions do play a role in Casechecking/assignment, it would thus appear that the postposition-like elements in Type D phrases (and the postpositions in Type C) lack this property, which raises doubts about their status as regular lexical adpositions.

The second consideration concerns the fact that PPs, specifically those of Types A, C and D, can occur either to the left or to the right of the verb or the verbal sequence in Afrikaans, as is illustrated in (15). ${ }^{7}$ 
(15) (a) Type A: Jy moet dit [voor Vrydag] doen / doen [voor Vrydag]

you must it before Friday do / do before Friday

'You must do it before Friday'

(b) Type C: Hy het [ $\underline{\text { met }}$ sy klere aan ] gaan slaap / gaan slaap [ $\underline{\text { met }}$ sy klere aan ] he has with his clothes on go sleep / go sleep with his clothes on 'He went to sleep with his clothes on'

(c) Type D: Ek wil [ $\underline{\text { met }}$ haar saam ] praat / praat [ $\underline{\text { met }}$ haar saam ]

I want-to with her with talk / talk with her with

'I want to talk to her'

However, as illustrated in (16), Type B phrases, especially those containing the postpositionlike elements associated with Type $\mathrm{D}$, cannot occur to the right of the verb/verbal sequence.

Type B (with postposition-like elements associated with Type D)

(16) (a) Hy het [daardie meisie mee] gepraat / *gepraat [daardie meisie mee ] he has that girl with PART-talk 'He talked to that girl'

(b) Ons sal [iemand anders voor ] moet stem / *moet stem [iemand anders voor ] we will someone else for must vote

'We'll have to vote for someone else'

(c) Hulle het weer [iemand van ] geskinder / *geskinder [iemand van ] they have again someone of PART-gossip

'They've again been gossiping about someone'

The ungrammaticality of the examples in (16) in which the DP and the postposition-like element appear in sentence-final position, can be explained straightforwardly if we assume that the postposition-like element does not have Case-checking/assignment properties. Hence, in this type of construction, the Case-feature of the DP argument would remain unchecked (or in terms of Case-assignment theory, the DP would be left without Case). The only way for 
this DP to check/receive its Case, would then be to move to the specifier position of some functional category above the VP, as in (17). ${ }^{8}$

(17) (a) Hy het daardie meisie gepraat [t $\underline{\text { mee }}$ ]

(b) Ons sal iemand anders moet stem [t $\underline{\text { voor }]}$

(c) Hulle het weer iemand geskinder [t $\underline{\text { van }}]$

Similarly, in the grammatical examples in (16) the DP argument can check/receive its Case by moving to the specifier position of some functional category above the relevant VP. Evidence for this type of movement is provided by sentences like those in (18); in both cases the DP has been separated from the postposition-like element, appearing to the left of a VP adverb in (a) and a modal auxiliary in (b).

(18) (a) Hy het daardie meisie dikwels mee gepraat

he has that girl often with PART-talk

'He often talked to that girl'

(b) Ons sal iemand anders moet voor stem

we will someone else must for vote

'We'll have to vote for someone else'

Returning to the examples in (16), it must be noted that a Type B construction can occur in sentence-final position if the DP takes the form daar ('there') or hier ('here') and forms a complex word with the postposition-like element. This is illustrated by the sentences in (19), which pattern exactly like those in (15).

(19) (a) Hulle het [daarvan ] gepraat / gepraat [daarvan ]

they have it-of PART-talk / PART-talk it-of

'They talked about it'

(b) Jy kan die vleis [hiermee ] sny /sny [hiermee ]

you can the meat this-with cut / cut this-with

'You can cut the meat with this' 
(c) Ek sal [hiermee ] tevrede wees / tevrede wees [hiermee]

I will this-with satisfied be / satisfied be this-with

'I'll be satisfied with this'

It could be argued that daar and hier in sentences like these do not represent DP arguments that have to be checked for (or assigned) Case, but rather that they are unprojected Ds, the Case-less variants of the determiner dit ('it', 'that', 'this'), that are merged with the postpositionlike element in initial structure. The latter would then form the head of a complex postposition or postposition-like word, which is not subject to Case-checking/assignment. The merit of such an analysis will not be examined further here.

On the basis of the four properties set out above, it could be argued that the postposition-like elements in Type D phrases do not belong to the class of regular lexical prepositions/ postpositions. This leaves one other possibility, namely that these elements belong to some sort of functional category. This possibility forms the basis of the two analyses that are considered in the next section.

\section{Underlying structure}

In his discussion of postpositional (= Type B) and circumpositional (= Type C) phrases in German and Dutch, Van Riemsdijk (1990: 239) proposes a single underlying structure for both construction-types. In this structure, presented in (20) below, a "functional preposition" $\mathrm{p}^{0}$ selects a PP to its left. Van Riemsdijk (1990: 240) goes on to suggest that "we can take the postpositional element to be base-generated" in the case of circumpositional phrases, and that "there is movement from $\mathrm{P}^{0}$ to $\mathrm{p}^{0}$ " in the derivation of postpositional phrases.

$$
\left[\mathrm{pp}\left[\mathrm{PP} \mathrm{P}^{0} \mathrm{NP}\right] \mathrm{p}^{0}\right]
$$

The question now is whether Van Riemsdijk's proposals provide an adequate framework for the description of adpositional constructions in Afrikaans. There are several considerations 
that suggest a negative answer to this question. Firstly, according to Van Riemsdijk (1990: 239), the functional prepositional head in (20) "serves to express certain locational dimensions where the lexical prepositional head does not do so itself." The selection of the functional preposition is therefore dependent on the semantic properties of the lexical preposition: if the latter fails to express certain locational dimensions, then the functional preposition is selected. By implication, the functional preposition should be absent if the lexical preposition does express the relevant locational dimensions. Within the Principles and Parameters framework, however, heads are generally assumed to select complements of a certain type, and not the other way round as is implied by Van Riemsdijk's analysis. For example, none of the other functional heads (C, T/I, D, etc.) seems to be selected on the basis of the properties of its complement. One would expect this assumption to hold also for functional prepositions. This, however, runs contrary to what is implied by Van Riemsdijk's analysis.

A second potential problem concerns the fact that the postposition-like elements in Afrikaans Type D circumpositional phrases can be omitted without any apparent semantic effect, as was pointed out in section 2. This indicates that the lexical prepositions in these phrases do express the relevant semantic information, which leaves unexplained the (optional) occurrence of the postposition-like elements.

Generalising the underlying structure in (20) to prepositional (= Type A) phrases, a third potential problem would be that it does not seem to explain why $\mathrm{p}^{0}$ is left empty in such cases, that is, why the functional head is not filled by a postposition-like element in initial structure or by the head of the PP complement via $\mathrm{P}^{0}$-to- $\mathrm{p}^{0}$ movement in derived structure. It could of course be argued that prepositional phrases, unlike postpositional and circumpositional phrases, do not have the underlying structure in (20), that is, that prepositional phrases are generated without a layer of functional structure. Obviously, however, it would be preferable to have the same general structure underlying all three types of adpositional phrases. ${ }^{9}$

As regards word order, the analysis in (20) is faced with two further potential problems. The first is from the viewpoint of MP, and more specifically those versions of MP that incorporate 
Kayne's (1994) theory of Antisymmetry. ${ }^{10}$ One of the implications of this theory is that all languages have the underlying order specifier-head-complement (S-H-C), with surface variation being the result of movement operations. ${ }^{11}$ Hence, in the case of PPs, all languages are analysed as having the underlying order preposition-complement. In the structure in (20), however, the functional preposition $\mathrm{p}^{0}$ occurs in head-final position, taking its PP complement to the left. Accordingly, this structure would be disallowed in the relevant versions of MP. Secondly, notice that the head-final order in the functional PP in (20) contrasts with the order in the lexical PP, in which the head precedes its NP complement. Even if one does not assume the hypothesis about a universal underlying S-H-C order, the question still remains why functional PPs are head-final, while regular lexical prepositions select their complements to the right. Van Riemsdijk (1990: 240) remarks as follows in this regard:

(21) "The analysis [in (20) --- J.O.] has the advantage of preserving the principle of uniform headedness. It does so, however, at the expense of assuming that headedness may be different, even within one and the same projection, for the lexical and the functional head: $\mathrm{P}$ is initial and $\mathrm{p}$ is final. This may well be the standard analysis of cases of mixed headedness."

At the level of descriptive grammar, the strongest and potentially most interesting version of the principle of Uniform Headedness states that a particular language fixes the headedness parameter in a uniform way, so that nouns, verbs, prepositions, etc. are all uniformly headfinal or head-initial. ${ }^{12}$ According to Van Riemsdijk (1990: 232), this version can "(p)robably" not be maintained for languages exhibiting mixed headedness, like Dutch and German. Instead, for such languages, he (1990: 232) suggests a weaker version of the principle, the one referred to in (21), in terms of which "headedness is at least uniform per category". Notice, however, that the analysis in (20) employs an even weaker version of the principle of Uniform Headedness: on this version, headedness within a PP is only uniform per functional or lexical preposition. As regards the final, speculative, remark in (21), this is presented without any independent supporting evidence from other projections involving asymmetrical headedness of lexical and functional categories. 
One last potential problem that may be noted here, again from the viewpoint of MP, concerns the derivation of postpositional phrases from the structure in (20). Van Riemsdijk (1990: 240) assumes that such phrases are derived via movement of $\mathrm{P}^{0}$ to $\mathrm{p}^{0}$, "movement of the type found in the verbal domain (V-to-I, I-to-C) and ... in noun phrases (N-to-D movement)." Notice that $\mathrm{P}^{0}$-to- $\mathrm{p}^{0}$ in (20) is an instance of rightward movement. Such an operation would be ruled out in those versions of MP that incorporate Kayne's theory of Antisymmetry. As was pointed out above, one of the implications of this theory is that all languages are underlyingly S-H-C. Hence, in a given projection, there would be no head in final position that could function as a landing site for rightward head movement. Interestingly, as far as could be ascertained from the available literature, this type of operation is not employed in other (standard) versions of MP either, that is, in versions that do not incorporate the theory of Antisymmetry. It is not clear, however, whether this absence of rightward head movement can be ascribed to some general principle in such cases.

In view of the potential problems set out above, it seems reasonable to conclude that the analysis in (20) does not provide an adequate framework for the description of adpositional phrases in Afrikaans. Let us now consider a possible alternative analysis, specifically of those phrases that contain postposition-like elements such as mee, voor, in, saam, van, etc. and/or prepositions that express the same thematic information as such elements. On this analysis, the structure underlying Type D phrases in Afrikaans may be represented as in (22).

$$
\left[{ }_{p \mathrm{P}} p[\mathrm{PP} \mathrm{P} \text { DP }]\right]
$$

The $p$ in (22) represents a "light preposition" --- similar to light agentive verbs, light eventive verbs, etc. --- that encodes semantic information like instrument, location, participant, goal, direction, etc. ${ }^{13}$ The light preposition may be abstract or, as in the case of Type D phrases, it may take the form of a postposition-like element such as mee, voor, in, uit, etc. It is assumed on the basis of the discussion in section 2 that the light preposition $p$ in (22), unlike the lexical preposition P, does not have any Case-checking properties. Note further that both PPs in (22) have the underlying order head-complement. This is in accordance with Kayne's (1994) theory 
of Antisymmetry, as well as with the version of the principle of Uniform Headedness which states, in Van Riemsdijk's (1990: 232) words, that "headedness is at least uniform per category", in this case the broad category PP.

Suppose that the light preposition $p$ in (22) is selected in the form of the postposition-like element mee ('with'), and then merged with the PP complement met 'n mes ('with a knife'). In order to derive the Type D circumpositional phrase met ' $n$ mes mee (as in (4)(a) above), the PP is moved to the left into the specifier position of $p$, as illustrated in (23). ${ }^{14}$

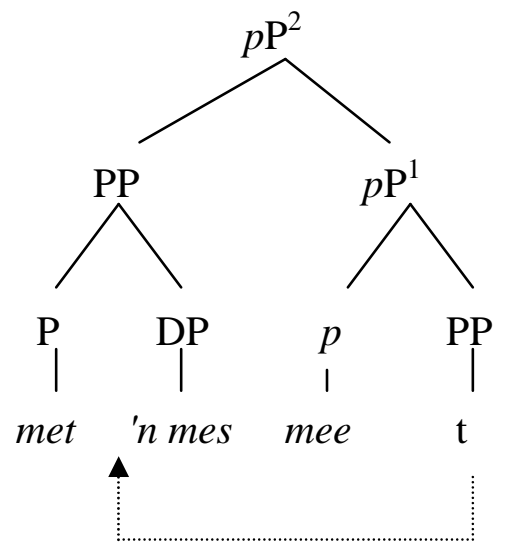

The obvious question, of course, is why the PP is fronted in (23), that is, whether there is any reason for moving the PP to the left of mee other than to yield the correct surface order. Recall that the preposition and the postposition-like element in Type D phrases are semantically the same in the sense that they express the same information about location, direction, instrument, goal, etc. Type D phrases in which these two items do not agree with regard to the semantic information that they express, are ungrammatical. This can be illustrated with the examples in (24): in the (a) sentence met has an instrument interpretation while voor expresses goal, and in (b) in expresses location and mee instrument. Both sentences are ungrammatical.

(24) (a) *Hy het my $\underline{\text { met }}$ 'n mes voor gesteek he has me with a knife for PART-stab

(b) *Sy braai die vleis in die pan mee she fries the meat in the pan with 
Within the Principles and Parameters framework, and more specifically within MP, agreement relationships are typically established via grammatical feature-checking in a specifier-head configuration. ${ }^{15}$ It seems reasonable, therefore, to assume that the PP complement in (23) moves to the specifier position of the light preposition $p$ in order to have some feature of its lexical head $\mathrm{P}$ checked against the corresponding feature of $p$, where this feature relates to a semantic property like instrument, location, goal, etc. If the features match, the PP is licensed and feature-deletion takes place; by contrast, mismatch of features results in the cancellation of the derivation. ${ }^{16}$ In short, for the PP to be formally licensed, it has to move to a position where it can enter into a feature-checking relation with the light preposition. In (23) this is the specifier position of $p$.

A potential problem facing the above analysis may be noted at this point. As illustrated in (25), the lexical PP in a structure like (23) can be wh-moved and topicalised. However, fronting of the DP complement on its own leads to ungrammaticality, as illustrated by the examples in (26).

(25) (a) Met watter mes moet ek die vleis $\underline{\text { mee }}$ sny?

with which knife must I the meat with cut

'With which knife should I cut the meat?'

(b) Vir hom sal ek nooit voor stem nie.

for him will I never for vote not

'I'll never vote for him'

(26) (a) *Watter mes moet ek die vleis $\underline{\text { met }} \underline{\text { mee }}$ sny?

(b) *Hom sal ek nooit vir voor stem nie

The question, then, is why the DP in (23) cannot be moved alone. A possible answer to this question is suggested by Radford (1997: 279) in his discussion of a similar phenomenon in formal styles of English. As was mentioned above, lexical prepositions are assumed in MP to be involved in checking the Case of their DP complements. Suppose that this is done in (23) 
by attraction of the Case-feature of the DP to the lexical preposition in the overt syntax, that is, before Spell-out. Suppose further that this attraction of the Case-feature triggers piedpiping of all the other grammatical features of the DP. ${ }^{17}$ Case-checking takes place if the Case-feature of the DP matches that of the lexical preposition, and results in feature-deletion. However, the other (unchecked) grammatical features of the DP, which may include a whfeature or a topic-feature, remain attached to the lexical preposition, from where they can percolate to the PP. Since attraction removes the wh- or topic-feature from the DP, the DP cannot be fronted on its own at a later stage of the derivation in order to check the relevant feature, which explains the ungrammaticality of the sentences in (26). Instead, it is the PP that must be moved for checking purposes, as in (25).

Returning to the structure in (22), it was claimed above that the light preposition $p$ can be either abstract or in the form of a postposition-like element (mee, voor, in, van, etc.). Let us now consider the consequences of selecting $\phi$, an abstract $p$. Suppose this $p$ is merged with the PP complement met ' $n$ mes. As in the case of (23), licensing of the PP involves moving it to the specifier position of the $p$ for feature-checking. Since the light preposition $\phi$ has no phonetic content, the resulting structure will exhibit the word order of a Type A phrase, that is, a regular prepositional phrase, as illustrated in (27).

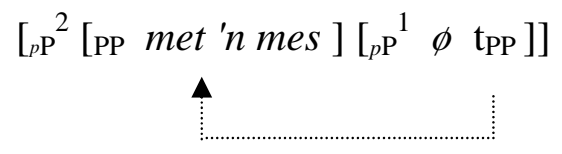

In terms of the analysis of Case-checking outlined above, the grammatical features of the DP in a structure like (27) are attracted to the lexical preposition, where checking of the Casefeature takes place. The other (unchecked) features of the DP --- which have been pied-piped along with the Case-feature, and which may include a wh- or a topic-feature --- subsequently percolate to the PP. It is thus predicted that the PP should be preposable under wh-Movement and Topicalisation, but not the DP on its own. This prediction is borne out by the facts, as is clear from the examples presented in (11) and (12) above. 
Let us consider next the derivation of Type B postpositional phrases, in particular those containing the postposition-like elements associated with Type D circumpositional phrases. Examples of such phrases were given in (16) above. In order to derive this type of phrase, the underlying structure in (22) would have to be expanded as in (28) to provide for the possibility of a DP complement for the light preposition.

$$
\left[{ }_{p \mathrm{P}} p[\mathrm{PP} / \mathrm{DP}]\right]
$$

As in (22), the light preposition in (28) may be abstract or it may be selected in the form of a postposition-like element (mee, voor, van, etc.). Suppose that the $p$ takes the form mee, and that it merges with the DP complement die tweede prys ('the second prize'), as in (29).

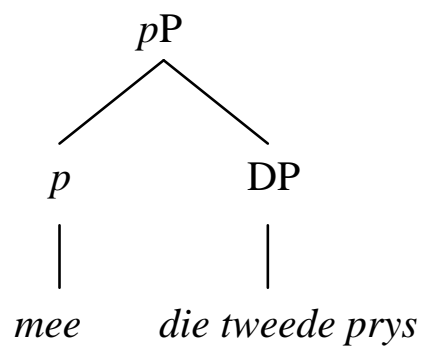

The DP in (29) has to be checked for Case. However, this cannot be done by mee since light prepositions do not have any Case-checking properties. The DP must therefore move to some Case-checking position outside of the $p \mathrm{P}$, otherwise its unchecked Case-feature will lead to ungrammaticality. This can be illustrated with the examples in (30). ${ }^{18}$ In (30)(a) the DP was moved out of the $p \mathrm{P}$ to a position higher up in the structure, presumably the specifier position of some functional category involved in Case-checking; this sentence is grammatical. In (30) (b) the DP occurs in its initial complement position, and in (30)(c) in the specifier position of mee; both sentences are ungrammatical.

(30) (a) Ek sal die tweede prys tevrede wees $\underline{\text { mee }}$

I will the second prize satisfied be with

'I'll be satisfied with the second prize' 
(b) *Ek sal tevrede wees mee die tweede prys

(c) *Ek sal tevrede wees die tweede prys mee

The $p \mathrm{P}$ occurs in sentence-final position in all three the examples in (30). It is also possible, however, for the $p \mathrm{P}$ to occur in pre-verbal position, as in (31).

$$
\begin{aligned}
& \text { Ek sal die tweede prys mee tevrede wees } \\
& \text { I will the second prize with satisfied be } \\
& \text { 'Ill be satisfied with the second prize' }
\end{aligned}
$$

An apparent problem arises at this point. The ungrammaticality of the sentence in (30)(c) can be explained on the basis of the assumption that a DP cannot be Case-checked in the specifier position of a light preposition. The question, then, is why the sentence in (31) is grammatical, since here, too, the DP die tweede prys appears to occupy the specifier position of the $p$ mee. A plausible answer is that the DP in (31) does not form part of the $p \mathrm{P}$, but that it in fact occupies a (Case-checking) position outside of the $p \mathrm{P}$. If this is so, it is predicted that the DP and the $p$ should be separable, for example by a sentential adverb like beslis ('certainly'), when the $p \mathrm{P}$ occurs in pre-verbal position. The prediction is borne out by the sentence in (32)(a). ${ }^{19}$ As is clear from the ungrammaticality of the sentences in (32)(b) and (c), the adverb cannot appear after the verb, irrespective of whether the DP has been raised or not.

(32) (a) Ek sal die tweede prys beslis mee tevrede wees

I will the second prize certainly with satisfied be

'I'll certainly be satisfied with the second prize'

(b) *Ek sal die tweede prys tevrede wees beslis $\underline{\text { mee }}$

(c) *Ek sal tevrede wees die tweede prys beslis $\underline{\text { mee }}$

The above analysis of Case-checking outside of the $p \mathrm{P}$ in sentences like those in (30)(a), (31) and (32)(a) also accounts for the fact that the DP in such constructions can be wh-moved and topicalised on its own, as illustrated in (33). By contrast, Case-checking will not take place if 
the DP remains part of the $p \mathrm{P}$ under wh-Movement and Topicalisation, which explains the ungrammaticality of the sentences in (34). ${ }^{20}$

(33) (a) Wat sal jy mee tevrede wees?

what will you with satisfied be

'What will you be satisfied with?'

(b) Die tweede prys sal ek tevrede wees $\underline{\text { mee }}$

the second prize will I satisfied be with

'The second prize I'll be satisfied with'

(34) (a) ?*Wat mee sal jy tevrede wees?

(b) ?*Die tweede prys mee sal ek tevrede wees

To end, let us briefly consider the possibility of merging the DP complement in the structure in (28) with an abstract light preposition $\phi$. This gives rise to ungrammaticality, as illustrated in (35)(a) and (b); in both cases the DP was raised out of the $p \mathrm{P}$ for Case-checking.

(35) (a) *Ek sal [DP die tweede prys $]\left[\begin{array}{lll}{ }_{p \mathrm{P}} & \phi & \mathrm{t}\end{array}\right]$ tevrede wees

I will the second prize satisfied be

(b) *Julle moet $\left[{ }_{D P}\right.$ daardie kandidaat $\left.]{ }_{p \mathrm{p}} \phi \mathrm{t}\right]$ stem

you must that candidate vote

It seems reasonable to assume that the semantic information expressed by a light preposition must be made phonologically visible in some way. This can be effected either through selection of a postposition-like element and/or through feature-agreement between the light preposition and a lexical preposition. The examples in (35) do not contain any overt element (for example, a lexical preposition such as met or vir and/or a postposition-like element such as mee or voor) that encodes the relevant information necessary for semantic interpretation, hence the ungrammaticality of these examples. 


\section{Summary}

This paper focused on a subtype of the circumpositional construction in (non-standard varieties of) Afrikaans, viz. those phrases in which the co-occurring preposition and postposition(-like element) encode the same semantic information. Examples of this subtype, referred to as "(construction-)type D", were presented in (4) above. It was argued in section 2 that the postposition-like elements in Type D phrases do not represent regular lexical adpositions, but that they rather belong to some sort of functional category. In section 3 we considered the underlying structure of Type D phrases. In this regard we first examined the merit of an analysis of circumpositional and postpositional phrases in German and Dutch that is proposed in (Van Riemsdijk 1990). In view of the potential problems facing that analysis, it was concluded that Van Riemsdijk's proposals do not represent an adequate framework for the description of Afrikaans adpositional phrases. We subsequently considered an alternative analysis, one which appears to overcome the potential problems facing the analysis in (Van Riemsdijk 1990). The central premises of this alternative analysis may be summarised as follows:

I. Type D circumpositional phrases, postpositional phrases with the same postposition-like elements as those found in Type D, and prepositional phrases with prepositions that express the same semantic information as such elements all have the same general underlying structure, viz. the one in (28) above: ${ }_{p \mathrm{P}} p$ [ PP/DP ]].

II. $\quad p$ in the structure in (28) represents a light preposition, a functional category that expresses semantic information like instrument, location, direction, participant, goal, and so on. The light preposition may be abstract or it may take the form of a postposition-like element such as mee, voor, in, uit, van, saam, etc. An abstract $p$ must be made phonologically visible through feature-agreement with a lexical preposition.

III. Unlike lexical prepositions, light prepositions do not have Case-checking properties. The DP complement of $p$ in the structure in (28) must therefore move to a position outside of the $p \mathrm{P}$ to have its Case checked. 
IV. The PP complement in the structure in (28) moves to the specifier position of the light preposition $p$ in order to have some feature of its lexical head $\mathrm{P}$ checked against the corresponding feature of $p$, where this feature relates to a semantic property like goal, location, direction, instrument, etc. If the features match, the PP is formally licensed; mismatch of features results in cancellation of the derivation.

Although the proposed analysis seems to provide an adequate description of the relevant facts of Afrikaans, several potentially interesting questions still need to be addressed. Two of these may be noted here as topics for further investigation. The first question concerns the category higher up in the structure --- that is, higher than the $p \mathrm{P}$ and the $\mathrm{VP}$--- that is involved in checking the Case of the DP complement in the structure in (28). It is not clear at this point what properties such a category might have or even whether its postulation could be justified on independent grounds. The second question is whether the structure in (28) could be generalised to other types of adpositional phrases, more specifically, to those adpositional phrases that contain neither the postposition-like elements associated with Type D phrases nor prepositions that express the same semantic information as such elements. To put it differently, it needs to be established whether all adpositional phrases have the underlying structure in (28), comprising an inner PP/DP core and an outer functional $p \mathrm{P}$ shell. 


\section{NOTES}

* A shortened version of this paper was read at the January 2000 conference of the Linguistics Society of Southern Africa at the University of Cape Town.

1. See e.g. Van Rensburg (1989) and the references cited there for Kaaps and other varieties of Afrikaans. For general, non-generative, descriptions of adpositional phrases in Afrikaans, see Ponelis (1979) and Donaldson (1993).

2. See also Aboh (1999: 152-162) for an analysis of circumpositional phrases in Gungbe that addresses similar questions to those raised above in connection with Afrikaans type D phrases.

3. See e.g. Jackendoff (1973); Radford (1997: 42).

4. This sentence is acceptable with the meaning 'He only talked to her', that is, if net is interpreted as modifying the verb gepraat rather than the element mee.

5. The acceptability judgements of native speakers vary considerably with regard to sentences like those in (13)(a) and (14)(a); some speakers seem to find such sentences marginally acceptable, or at least not fully unacceptable.

6. See e.g. Culicover (1997: chapter 2); Lasnik (1999: 52-53); Ouhalla (1999: chapter 8; 433-7).

7. See Barbiers (1995: chapter 4) for an interesting analysis of this phenomenon in Dutch.

8. Lasnik (1999: 53) mentions the possibility that such a functional category is involved in checking the Case of the DP complement in regular prepositional phrases. See also Radford (1997: 451-454).

9. Van Riemsdijk (1990: 239) proposes that "PPs in German and Dutch" (my emphasis ---J.O.) have the underlying structure in (20). It is not clear, however, whether this proposal is intended to apply also to prepositional (= Type A) phrases.

10. See e.g. Bennis (1995), Culicover (1997: 373-384) and Ouhalla (1999: chapter 20) for accessible discussions of the content and the consequences of Kayne's theory of Antisymmetry. For a critical discussion of this theory, see Chomsky (1995a).

11. See e.g. Zwart (1997) for a detailed analysis of Dutch as an underlying S-H-C language.

12. At the level of universal grammar, the strongest hypothesis would be that all languages have the same underlying order. For example, as noted above, one of the implications of Kayne's (1994) theory of Antisymmetry is that all languages are underlyingly S-H-C, that is, head-initial.

13. See e.g. Chomsky (1995b: 315-323), Hale \& Keyser (1993), and Larson (1988) for the notion 'light verb' and the related notion 'VP shell'. For accessible discussions of these notions, see e.g. Culicover (1997: 364-373) and Radford (1997: chapter 9). See also Radford (1997: 451-454) for the notion 'light preposition'. 
14. More accurately, the lexical PP is left-adjoined to the functional $\mathrm{PP}, p \mathrm{P}^{1}$, yielding the twosegment functional projection $p \mathrm{P}^{2}$.

15. See e.g. Chomsky (1995b: 178, 196, 255-260); Ouhalla (1999: 434). Chomsky (1995b: 257) states that "(n)o property can be checked in the head-complement structure".

16. See Chomsky (1995b: 281, 309) in connection with feature-deletion and (mis)matching of features.

17. It is also possible, of course, that Case-checking via feature-attraction takes place before the PP complement in (23) is raised to the specifier position of the light preposition. For a detailed discussion of feature-movement/attraction, see Chomsky (1995b: 261-271).

18. See also the examples in (16) and (17) above.

19. See also the examples in (18) above.

20. See also the examples in (13) and (14) above. 


\section{REFERENCES}

Aboh, E.O. 1999. From the syntax of Gungbe to the grammar of Gbe. Doctoral thesis, University of Geneve.

Barbiers, S. 1995. The syntax of interpretation. HIL dissertations, 14. The Hague: Holland Academic Graphics.

Barbiers, S. 2000. The right periphery in SOV languages: English and Dutch. In P. Svenonius (ed.). 2000. The derivation of $V O$ and $O V$. Linguistik Aktuell, 31. Amsterdam: John Benjamins.

Bennis, H. 1995. Waar is het werkwoord? Deel II: antisymmetrie. Spektator, 24(2): 130-146.

Chomsky, N. 1995a. Bare phrase structure. In G. Webelhuth (ed.). 1995. Government and binding theory and the minimalist program. Oxford: Blackwell.

Chomsky, N. 1995b. The minimalist program. Cambridge, Mass.: MIT Press.

Culicover, P. 1997. Principles and parameters. An introduction to syntactic theory. Oxford: Oxford University Press.

Donaldson, B. 1993. A grammar of Afrikaans. Berlin \& New York: Mouton de Gruyter.

Hale, K. \& S.J. Keyser. 1993. On argument structure and the lexical expression of semantic relations. In K. Hale \& S.J. Keyser (eds.). 1993. The view from Building 20. Cambridge, Mass.: MIT Press.

Jackendoff, R.S. 1973. The base rules for prepositional phrases. In S.R. Anderson \& P. Kiparsky (eds.). 1973. A Festschrift for Morris Halle. New York: Holt.

Kayne, R.S. 1994. The antisymmetry of syntax. Cambridge, Mass.: MIT Press.

Larson, R. 1988. On the double object construction. Linguistic Inquiry, 19: 335-391.

Lasnik, H. 1999. Minimalist analysis. Oxford: Blackwell.

Ouhalla, J. 1999. Introducing transformational grammar. From principles and parameters to minimalism (2nd edition). London: Arnold.

Ponelis, F.A. 1979. Afrikaanse sintaksis. Pretoria: Van Schaik.

Radford, A. 1997. Syntactic theory and the structure of English. A minimalist approach. Cambridge: Cambridge University Press.

Van Rensburg, M.C.J. 1989. Soorte Afrikaans. In T.J. Botha, F.A. Ponelis, J. Combrink \& F. Odendal (eds.). 1989. Inleiding tot die Afrikaanse taalkunde (2nd edition). Pretoria: Academica. 
Van Riemsdijk, H. 1990. Functional prepositions. In H. Pinkster \& I. Genee (eds.). 1990. Unity in diversity. Papers presented to Simon C. Dik on his 50th birthday. Dordrecht: Foris Publications.

Zwart, J.W. 1997. Morphosyntax of verb movement. A minimalist approach to the syntax of Dutch. Dordrecht: Kluwer Academic Publishers. 
Please ignore this page; the paper ends on page 90.

1
2
3
4
5
6
7
8
9
10
11
12
13
14
15
16
17
18
19
20

